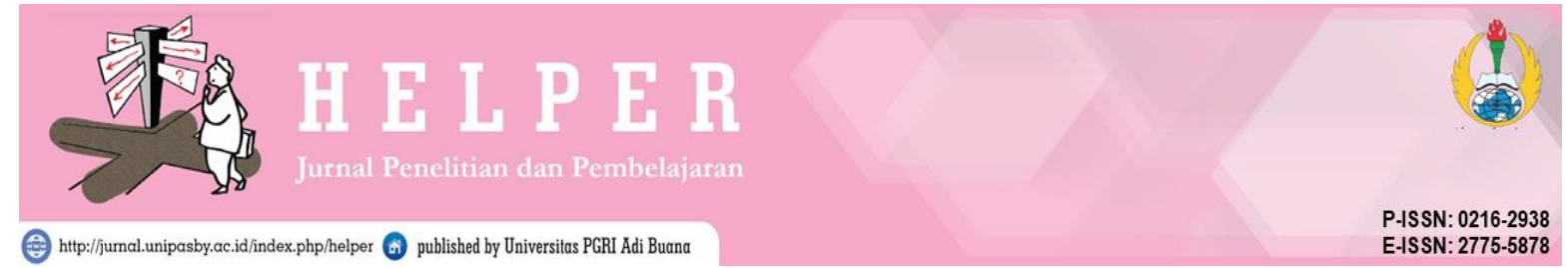

Vol. 38 No. 1 (2021)

\title{
PENERAPAN KONSELING KELOMPOK TEKNIK KONTRAK UNTUK MENINGKATKAN KEDISIPLINAN BELAJAR SISWA KELAS VIII SMP NEGERI 2 PORONG
}

\author{
Rays Tri Prasetya, Mudhar \\ Bimbingan dan Konseling, Fakultas Pedagogi dan Psikologi, \\ Universitas PGRI Adi Buana Surabaya \\ Email: raystrip0@gmail.com, mudhar@unipasby.ac.id
}

\begin{abstract}
Abstrak
Penelitian ini dilatarbelakangi oleh kurangnya kedisiplinan belajar siswa saat ini. Ditambah dengan adanya covid-19 yang mengakibatkan harus belajar dirumah sehingga siswa tidak memiliki kesadaran dalam belajar, tidak mengikuti pembelajaran secara optimal dan mengerjakan tugas. Tujuan yang ingin dicapai pada penelitian ini untuk mengetahui pengaruh teknik kontrak untuk meningkatkan kedisiplinan belajar siswa kelas VIII E di SMP Negeri 2 Porong. Penelitian ini menggunakan pendekatan penelitian kuantitatif dengan menggunakan One group pretest-posttest design. Subyek penelitian adalah siswa kelas VIII E sebanyak 5 siswa. Metode pengumpulan data yang digunakan adalah angket kedisiplinan belajar siswa. Metode analisis data yang digunakan adalah uji Wilcoxon. Berdasarkan hasil analisis, dapat disimpulkan bahwa kedisiplinan belajar siswa secara signifikan dapat ditingkatkan melalui konseling kelompok dengan teknik kontrak.
\end{abstract}

Kata Kunci: teknik kontrak, kedisiplinan belajar

\begin{abstract}
Abstact
This research is motivated by the lack of discipline in student learning at this time. Coupled with covid-19 which resulted in having to study at home so that students did not have awareness in learning, did not participate in learning optimally and did assignments. The aim of this research is to know the effect of contract technique to improve the learning discipline of students of class VIII E at SMP Negeri 2 Porong. This study uses a quantitative research approach using One group pretest-posttest design. The research subjects were 5 students of class VIII E. The data collection method used was a student learning discipline questionnaire. The data analysis method used was the Wilcoxon test. Based on the results of the analysis, it can be concluded that students' critical thinking skills can be significantly improved through group counseling with contract techniques.
\end{abstract}

Keywords: contract technique, discipline learning 
Penerapan Konseling Kelompok Teknik Kontrak Untuk Meningkatkan Kedisiplinan Belajar Siswa Kelas VIII SMP Negeri 2 Porong

\section{PENDAHULUAN}

Masa remaja merupakan masa peralihan dimana individu mengalami peralihan dari anak-anak menuju dewasa, masa dimana individu tersebut dalam proses pencarian jati diri. Menurut (Santrock, 2003) remaja masa anak-anak dan masa dewasa mengalami perubahan yang mencakup sosioemosional, biologis, dan kognitif. Perubahan pada masa remaja yang terjadi baik fisik maupun secara psikologis mengakibatkan timbul beberapa permasalahan. Siswa tidak jarang melanggar tata tertib sekolah seperti tidak mengerjakan tugas karena kurangnya kedisiplinan belajar pada siswa.

Kurangnya kesadaran siswa dalam kedisiplinan belajar dapat mengakibatkan siswa tidak mengikuti pembelajaran secara optimal dan mempengaruhi prestasi akademik dari siswa. Ditambah dengan adanya pandemi covid 19 ini siswa dituntut untuk melakukan kegiatan pembelajaran secara daring melalui berbagai aplikasi online. Selama pandemi covid-19 ini guru dan siswa belum dikatakan efektif dalam proses pembelajaran dikarenakan minimnya teknologi yang dimiliki untuk mengikuti pembelajaran jarak jauh atau daring. Pandemi covid-19 juga mengakibatkan siswa merasa jenuh dalam mengikuti proses pembelajaran secara daring dan pengetahuan siswa juga semakin menurun, Sehingga dapat menyebabkan menurunnya prestasi belajar siswa.

Berdasarkan hasil wawancara terhadap guru di masa pandemi covid 19 dapat diketahui bahwa kurangnya kesadaran dalam melaksanakan kewajiban peserta didik seperti: kurangnya respon peserta didik dalam pembelajaran, mengumpulkan tugas tidak tepat pada waktunya dan beberapa peserta didik tidak mengumpulkan tugas. Hal ini menjadi indikator dari kurangnya disiplin.

Kedisiplinan belajar merupakan kondisi dimana seseorang melakukan kegiatan belajar, mengerjakan tugas dengan baik dan mampu mengontrol dirinya untuk belajar atas kesadaran dirinya sendiri tanpa paksaan dari siapapun. (Rohman , 2009) mengartikan disiplin belajar adalah kondisi yang terbentuk melalui perilaku seseorang untuk memperoleh perubahan tingkah laku baru dan merupakan hasil pengalamannya dengan lingkungannya. Lingkungan juga berpengaruh terhadap perilaku disiplin belajar siswa, jika siswa tidak mempunyai kesadaran diri untuk mengerjakan maka tugas tersebut tidak terselesaikan dengan baik. Oleh karena itu diharapkan siswa dapat disiplin dalam proses pembelajaran.

Dampak yang terjadi jika siswa tidak meningkatkan kedisiplinan belajar maka siswa tersebut tidak mampu mengontrol dirinya dan tidak mempunyai kesadaran dalam dirinya sehingga malas dalam belajar kemudian tidak mengerjakan tugas, sehingga hal tersebut dapat berpengaruh terhadap prestasi belajarnya. Menurut (Widosari, 2014)perilaku ketidakdisiplinan siswa akan berdampak pada prestasi belajar maupun mental siswa, sehingga mengakibatkan kurang berkembang dalam prestasi belajar. Dapat disimpulkan bahwa dampak yang terjadi jika siswa tidak melakukan kedisiplinan dalam belajar, siswa akan ketinggalan pelajaran yang berdampak pada prestasi belajar. 
Penerapan Konseling Kelompok Teknik Kontrak Untuk Meningkatkan Kedisiplinan Belajar Siswa Kelas VIII SMP Negeri 2 Porong

Terdapat beberapa faktor yang mempengaruhi kedisiplinan belajar siswa, menurut (Suradi, 2011)salah satunya adalah faktor sosial. Faktor lingkungan sosial tersebut sangat berpengaruh dalam kedisiplinan belajar siswa. Seorang siswa yang berada dalam lingkungan sosial yang disiplin maka siswa tersebut akan mempunyai sikap disiplin yang kuat. Kedisiplinan belajar siswa juga memerlukan dukungan dari semua lingkup lingkungan sosialnya, khususnya siswa itu sendiri. Tidak luput juga peran guru bk sebagai guru yang membantu menyelesaikan sebuah permasalahan.

Bimbingan dan konseling dapat membantu siswa menyelesaikan permasalahan melalui layanan konseling kelompok. konseling kelompok adalah proses pemberian bantuan kepada siswa melalui suatu kelompok untuk menggali informasi permasalahan yang sedang dihadapi, yang diharapkan mampu membantu menyelesaikan masalah yang dimiliki oleh siswa secara tepat dan efektif. (Kurnanto, 2013)menjelaskan bahwa konseling kelompok adalah proses layanan yang dilakukan dalam bentuk kelompok, dimana konseli berinteraksi dengan konselor dalam kelompok untuk membantu permasalahan yang dihadapi oleh konseli secara bersama-sama. Berdasarkan pengertian tersebut dapat disimpulkan bahwa konseling kelompok adalah layanan yang dapat digunakan untuk membantu permasalahan kurangnya disiplin belajar siswa yang merupakan sebuah perilaku yang dapat dikurangi untuk mendorong siswa agar lebih disiplin dalam belajar melalui layanan konseling kelompok dengan teknik behavior kontrak.

Meningkatkan kesadaran siswa terhadap kedisiplinan belajar dapat dilakukan melalui teknik kontrak dengan menuliskan perilaku yang tidak diharapkan dan mengubahnya menjadi perilaku yang lebih baik. Teknik behavior kontrak adalah suatu teknik yang dilakukan atas dasar persetujuan dua orang atau lebih untuk mengubah perilaku tertentu pada seseorang. (Erdford, 2016)kontrak perilaku dapat digunakan untuk mengerjakan, mengurangi, dan meningkatkan perilaku yang diharapkan. Teknik behavior kontrak seseorang melakukan kesepakatan tertulis untuk mengubah perilaku seseorang apabila dia mampu merubah perilaku tersebut maka akan mendapatkan reward atau hadiah, apabila dia tidak mampu merubah perilaku tersebut akan mendapat punishment atau hukuman. Sehingga, dengan adanya layanan konseling kelompok teknik behavior kontrak diharapkan mampu menekankan perilaku disiplin belajar siswa.

\section{METODE}

\section{Desain Penelitian}

Metode penelitian kuantitatif merupakan metode penelitian yang menekankan pada analisis data-data numerical (angka) yang diolah dengan metode statistika, menurut (Azwar, 2007)Untuk mencapai tujuan yang diharapkan dalam penelitian ini, diperlukan suatu rancangan penelitian dan pelaksanaan penelitian. Adapun rancangan penelitian ini menggunakan rancangan One Group PretestPosttest Design yaitu pada rancangan penelitian ini mula-mula suatu kelompok subyek diberikan pre- 
Penerapan Konseling Kelompok Teknik Kontrak Untuk Meningkatkan Kedisiplinan Belajar Siswa Kelas VIII SMP Negeri 2 Porong

test kemudian dilaksanakan perlakuan pada waktu tertentu kemudian dilakukan pengukuran kembali post-test untuk membandingkan keadaan sesudah dan sebelum diberikan perlakuan. Alasan peneliti menggunakan desain ini adalah dalam penelitian ini peneliti akan membandingkan keadaan sampel sebelum diberikan perlakuan dan sesudah diberikan perlakuan, sehingga pada desain ini tidak memiliki kelompok kontrol untuk membandingkan keadaan sampel yang akan peneliti berikan perlakuan. Untuk mengetahui apakah adanya perubahan signifikan telah melakukan dua kali penilaian. Penilaian awal (pretest) dilakukan untuk melihat kondisi sampel sebelum diberikan perlakuan dan penilaian akhir (posttest) setelah diberi perlakuan. Dengan demikian hasil perlakuan lebih akurat, karena dapat membandingkan dengan keadaan sebelum diberi perlakuan. Rancangan penelitian ini dapat digambarkan sebagai berikut:

\begin{tabular}{|rcc|}
\hline Pre-test & Treatment & Post-test \\
\hline $\mathrm{T} 1$ & $\mathrm{X}$ & $\mathrm{T} 2$ \\
\hline
\end{tabular}

Rancangan Penelitian One Group Pre-Test Post-Test Design (Suryabrata, 2014)

Keterangan :T1=Pre-test untuk mengukur kedisiplinan belajar siswa sebelum diberikan layanan konseling kelompok dengan menggunakan teknik kontrak.

$\mathrm{X}=$ Perlakuan atau treatment (pemberian layanan konseling kelompok dengan menggunakan teknik kontrak.

T2=Post-test untuk mengukur kedisiplinan belajar siswa sesudah diberikan layanan konseling kelompok dengan menggunakan teknik kontrak.

\section{Populasi dan Sampel}

Populasi penelitian ini adalah siswa kelas VIII- E SMP Negeri 2 Porong sebanyak 35 orang siswa. Sampel merupakan bagian dari populasi yang diteliti. Pada penelitian ini, peneliti mengambil sampel sebanyak 5 siswa menggunakan skala pengukuran kedisiplinan belajar.

\section{Instrumen Penelitian}

Penelitian kuantitatif memerlukan instrumen yang berkualitas berkenaan dengan validitas dan reliabilitas instrumen dan kualitas pengumpulan data berkenaan cara-cara yang digunakan untuk mengumpulkan data. Penelitian merupakan aktivitas yang dilakukan peneliti dalam upaya menemukan data empiris yang benar dalam arti terpercaya. Pada penelitian ini untuk mengumpulkan data penelitian digunakan instrumen penelitian yaitu skala pengukuran kedisiplinan belajar siswa. Instrumen yang digunakan dalam penelitian ini adalah skala pengukuran. Skala pengukuran adalah kesepakatan yang digunakan sebagai acuan atau tolak ukur untuk menentukan panjang pendeknya 
Penerapan Konseling Kelompok Teknik Kontrak Untuk Meningkatkan Kedisiplinan Belajar Siswa Kelas VIII SMP Negeri 2 Porong

interval yang ada pada alat ukur sehingga bila digunakan dalam pengukuran akan menghasilkan data. Berdasarkan definisi operasional variabel permasalahan kedisiplinan belajar selanjutnya peneliti menyusun kisi-kisi(blue-print).

\section{Teknik Analisis Data}

Teknik analisis data merupakan cara yang dilakukan untuk menganalisis terhadap data dengan tujuan agar dapat menjawab rumusan masalah. Apabila telah terkumpul data yang diperlukan dalam penelitian, untuk memperoleh hasil data yang diolah terlebih dahulu melalui analisis data. Analisis data dilakukan dengan uji wilcoxon menggunakan aplikasi SPSS versi 26.

Teknik analisis ini digunakan untuk menguji hipotesis penerapan konseling kelompok teknik kontrak untuk meningkatkan kedisiplinan belajar siswa di SMPN 2 Porong. Kaidah analisis yang digunakan adalah, hipotesis alternatif (ha) didukung jika peluang kesalahan (p) $\leq 0,05$ atau pada taraf signifikasi 95\%. Program statistika yang digunakan untuk melakukan analisis data adalah SPSS for Windows 26.0.

\section{HASIL}

Pada bab ini peneliti akan menyajikan data yang diperoleh setelah dilakukan Pre-test, yang mana dari Pre-test tersebut akan diketahui berapa jumlah subyek yang akan mendapat perlakuan teknik kontrak. Rentang penelitian pada skala pengukuran sikap kedisiplinan belajar siswa dalam penelitian ini menggunakan rentang skor dari 1 sampai 4 dengan banyak item 43 butir pernyataan.

Penelitian ini dilakukan dengan menyebarkan pertanyaan atau angket kepada 35 siswa kelas VIII E di SMP Negeri 2 Porong. Para siswa mengisi setiap butir pertanyaan sesuai dengan dirinya dan hasil dari angket tersebut dikategorikan menjadi beberapa tingkatan yaitu sangat tinggi, tinggi, sedang dan rendah pada masalah kedisiplinan belajar mereka. Dari hasil instrumen angket tersebut didapatkan 5 siswa yang mempunyai nilai yang rendah dan akan menjadi responden dalam konseling kelompok. Berikut adalah hasil pre test terendah dari kelas VIII E SMP Negeri 2 Porong:

\begin{tabular}{cccc}
\hline No. & Responden & Total & Kategori \\
\hline 1. & NKA & 98 & Rendah \\
2. & NQW & 93 & Rendah \\
3. & ANN & 92 & Rendah \\
4. & YNF & 90 & Rendah \\
5. & JRW & 86 & Rendah
\end{tabular}

Tabel 1. Hasil pre-test terendah kelas VIII E SMP Negeri 2 Porong

Setelah melakukan pre-test tersebut didapatkan 5 siswa yang mempunyai nilai kedisiplinan belajarnya yang rendah, maka perlu dilakukan proses konseling kelompok dengan menggunakan teknik kontrak untuk meningkatkan kedisiplinan belajarnya dengan melalui beberapa tahap. Berikut tahap dalam konseling kelompok teknik kontrak: 
Penerapan Konseling Kelompok Teknik Kontrak Untuk Meningkatkan Kedisiplinan Belajar Siswa Kelas VIII SMP Negeri 2 Porong

Pada pertemuan pertama konselor membangun hubungan baik dengan konseli. Pada pertemuan kedua mulai pada pembahasan permasalahan dengan berdiskusi permasalahan apa saja yang mengakibatkan kurangnya kedisiplinan belajar. Pertemuan ketiga mereview diskusi pada pertemuan sebelumnya dan pemberian treatment menggunakan teknik kontrak. Pertemuan keempat menanyakan kepada konseli dan merefleksikan apakah konseli sudah mampu meningkatkan kedisiplinan belajar. Pertemuan kelima memonitor apakah perilaku konseli dapat menetap dan memberikan post-test. Pertemuan keenam atau terakhir evaluasi dari hasil treatment dari awal sampai akhir pertemuan dan pemberian reward atau punishment. Dari hasil konseling kelompok dengan menggunakan teknik kontrak tersebut siswa mampu meningkatkan kedisiplinan belajarnya. Berikut hasil post-test dari kelas VIII E SMP Negeri 2 Porong:

\begin{tabular}{cccccc}
\hline No. & Responden & Pre-test & Kategori & Post-test & Kategori \\
\hline 1. & NKA & 98 & Rendah & 125 & Tinggi \\
2. & NQW & 93 & Rendah & 110 & Sedang \\
3. & ANN & 92 & Rendah & 121 & Tinggi \\
4. & YNF & 90 & Rendah & 123 & Tinggi \\
5. & JRW & 86 & Rendah & 119 & Sedang
\end{tabular}

Tabel 2. Hasil perbandingan pre-test dan post-test disiplin belajar siswa kelas VIII-E SMP Negeri 2 Porong

Tabel diatas menunjukkan bahwa setiap responden dikategorikan rendah, presentase pada setiap individu mengalami kenaikan. Hasil dari post-test yang telah diberikan kepada 5 responden penelitian mengalami kenaikan disiplin belajar dari kategori rendah menjadi sedang dan tinggi. Masing-masing konseli mengalami kenaikan disiplin belajar yang disebabkan oleh beberapa faktor kehidupan yang melatarbelakangi yang dialami oleh responden.

\section{Pembahasan}

Pada penelitian ini, analisis yang digunakan adalah teknik analisis non-parametrik dengan menggunakan metode uji Wilcoxon. Karena sampel yang diambil relatif kecil, dan untuk menganalisis hasil-hasil pengamatan yang berpasangan dari dua data apakah terdapat perubahan atau tidak. Manfaat dari test dalam penelitian ini adalah untuk menentukan ada atau tidaknya pengaruh yang ditimbulkan sebelum dan sesudah diberikan treatment. Hasil uji wilcoxon sebagai berikut:

\begin{tabular}{|l|c|c|c|}
\hline \multicolumn{4}{|c|}{ Ranks } \\
\hline & N & Mean Rank & Sum of Ranks \\
\hline
\end{tabular}


Penerapan Konseling Kelompok Teknik Kontrak Untuk Meningkatkan Kedisiplinan Belajar Siswa Kelas VIII SMP Negeri 2 Porong

\begin{tabular}{|l|l|r|r|r|}
\hline $\begin{array}{l}\text { Posttest }- \\
\text { Pretest }\end{array}$ & Negative Ranks & $0^{\mathrm{a}}$ &, 00 &, 00 \\
\cline { 2 - 5 } & Positive Ranks & $5^{\mathrm{b}}$ & 3,00 & 15,00 \\
\cline { 2 - 5 } & Ties & $0^{\mathrm{c}}$ & & \\
\cline { 2 - 5 } & Total & 5 & & \\
\hline
\end{tabular}

a. Posttest < Pretest

b. Posttest $>$ Pretest

c. Posttest $=$ Pretest

\section{Test Statistica}

\begin{tabular}{|l|r|}
\hline \multicolumn{2}{|c|}{ Test Statistics $^{\text {a }}$} \\
\hline & $\begin{array}{c}\text { Posttest - } \\
\text { Pretast }\end{array}$ \\
\hline$Z$ & $-2,032^{b}$ \\
\hline $\begin{array}{l}\text { Asymp. Sig. (2- } \\
\text { tailed) }\end{array}$ &, 042 \\
\hline
\end{tabular}

a. Wilcoxon Signed Ranks Test

b. Based on negative ranks.

Tabel 3. Hasil Uji Wilcoxon Kedisiplinan Belajar Siswa Kelas VIII-E SMP Negeri 2 Porong

Hasil interpretasi data ini menggunakan uji wilcoxon adalah sebagai berikut.

a. Negative Ranks atau selisih(negatif) antara kedisiplinan belajar siswa untuk pre-test dan post-test adalah 0, baik itu pada nilai N(negatif), Mean Rank (rata-rata peningkatan), maupun Sum Rank(jumlah ranking). Nilai 0 ini menunjukkan tidak adanya penurunan(pengurangan) dari nilai pre-test ke nilai post-test.

b. Positif Ranks atau selisih (positif) antara kedisiplinan belajar siswa untuk pre-test dan post-test. Disini terdapat 5 data positif(N) yang artinya ke 5 siswa mengalami peningkatan kedisiplinan belajar dari nilai pre-test dan post-test. Mean rank(rata-rata peningkatan) tersebut sebesar 3,00, sedangkan sum rank(jumlah ranking) sebesar 15,00.

c. Ties adalah kesamaan nilai pre-test dan post-test, disini nilai ties adalah 0 , sehingga dapat dikatakan bahwa tidak ada nilai yang sama antara pre-test dan post-test. 
Penerapan Konseling Kelompok Teknik Kontrak Untuk Meningkatkan Kedisiplinan Belajar Siswa Kelas VIII SMP Negeri 2 Porong

Berdasarkan hasil analisis uji wilcoxon pada tabel test statistics diatas diketahui Asymp. Sig (2-tailed) bernilai 0,042. Karena nilai 0,042 lebih kecil dari < 0,05, maka dapat disimpulkan bahwa Ha diterima. Artinya ada perbedaan antara kedisiplinan belajar untuk pre-test dan post-test, sehingga dapat disimpulkan bahwa terdapat pengaruh penggunaan konseling kelompok teknik kontrak untuk meningkatkan kedisiplinan belajar siswa kelas VIII-E SMP Negeri 2 Porong.

Hal ini juga sejalan dengan penelitian yang dilakukan pada siswa kelaS VIII SMP Negeri 6 Tarakan terdapat peningkatan disiplin belajar siswa sebelum dan sesudah diberikan teknik behavior contract. Sehingga teknik behavior contract dikatakan mampu meningkatkan disiplin belajar pada siswa kelas VIII SMP Negeri 6 Tarakan. Berdasarkan hasil analisis terhadap penelitian yang dilakukan terhadap 7 (Tujuh) orang siswa sebagai subjek penelitian, dapat dikatakan bahwa terdapat keterkaitan antara teori dan kenyataan yang terjadi pada saat dilaksanakannya penelitian. Hasil penelitian menunjukkan terdapat perbedaan skor disiplin belajar siswa, terlihat dari hasil pretest sebelum diberikan teknik behavior contract dan hasil posttest setelah diberikan teknik behavior contract.

\section{KESIMPULAN}

Berdasarkan hasil penelitian yang telah dilakukan dan pembahasan penelitian mengenai penerapan konseling kelompok teknik kontrak untuk meningkatkan kedisiplinan belajar siswa kelas VIII E SMP Negeri 2 Porong, maka dapat disimpulkan bahwa: Kedisiplinan belajar siswa kelas VIII E SMP Negeri 2 Porong sebelum diberikan konseling kelompok dengan teknik kontrak menunjukkan kategori rendah.

Kedisiplinan belajar siswa kelas VIII E SMP Negeri 2 Porong sesudah diberikan konseling kelompok dengan teknik kontrak menunjukkan kategori sedang dan tinggi. Peningkatan kedisiplinan belajar dapat dilihat dari nilai skor rata-rata kedisiplinan belajar siswa, hal tersebut dilihat dari tahap Pretest hingga Postest. Hasil tersebut diantaranya: Rata-rata skor pada Pretest 91,8 dan Rata-rata skor Posttest 119,6.

Terdapat perbedaan yang signifikan antara hasil pre-test dan post-test, sehingga dapat disimpulkan bahwa "penerapan teknikkontrak dalam konseling kelompok ada pengaruh untuk meningkatkan kedisiplinan belajar siswa".

\section{DAFTAR PUSTAKA}

Azwar, S. 2007. Metode Penelitian. Yogyakarta: Pustaka Pelajar.

Erdford, B. 2016. 40 teknik yang harus diketahui setiap konselor. Yogyakarta: Pustaka Pelajar. 
Penerapan Konseling Kelompok Teknik Kontrak Untuk Meningkatkan Kedisiplinan Belajar Siswa Kelas VIII SMP Negeri 2 Porong

Kardi, Y. 2016. Pengaruh Kedisiplinan Belajar dan Minat Belajar Terhadap Prestasi Belajar Siswa Kelas VIII SMP Negeri 1 Dagangan Kabupaten Madiun Tahun Ajaran 2010/2011,. Counsellia:Jurnal Bimbingan dan Konseling 2.1.

Kurnanto, M. 2013. Konseling Kelompok. Bandung: ALFABET.

Reswatiyo, A. 2019. Pengaruh teknik behavior contract terhadap disiplin belajar siswa kelas viii smpn 6 tarakan tahun pelajaran 2018/2019. 23-30.

Rohman , F. 2009. Pengaruh disiplin dan motivasi belajar. Retrieved November 08, 2020, from hhtp://faisalrohman.blogspot.com/2009/03/pengaruh-disiplin-dan-motivasibelajar.html.

Santrock, J. 2003. Perkembangan Remaja. Jakarta: Erlangga.

Suradi, S. 2011. Pentingnya Penerapan Disiplin Siswa di SMK Negeril Mesuji Raya. Retrieved November 08, 2020, from smkn1mesujiraya.blogspot.com.

Suryabrata, S. 2014. Metodologi Penelitian . Jakarta: Rajawali Pers.

Widosari, L. 2014. Upaya meningkatkan kedisiplinan melalui layanan bimbingan kelompok dengan teknik behavior pada siswa . Jurnal ilmiah pendidikan bimbingan dan konseling, 2(1), 56-62. 